\title{
CHARACTERISTICS OF BILIGENIC FUNCTION OF LIVER IN RESPONSE TO CRANIO-SKELETAL TRAUMA COMPLICATED BY HAEMORRHAGE
}

\section{Characteristics of biligenic function of liver in response to cranio-skeletal trauma complicated by haemorrhage}

\author{
T. A. Zaiets, T. V. Boiko, S. V. Dzyha, H. H. Habor \\ I. Horbachevsky Ternopil National Medical University
}

e-mail: djashunata@tdmu.edu.ua

Summary. Recently, functional state of the liver as a central organ of the body detoxification has been studied as a model of multiple organ dysfunction development in cases of severe experimental trauma. Organ-specific biliation and biligenic functions of the liver are sensitive indicators of its failure and are associated with the declination of the main markers of traumatic disease.

The aim of the study - to find out the dynamics of indicators of biligenic function of the liver in response to cranial skeletal trauma associated with haemorrhage.

Materials and Methods. Experiments were performed on 54 outbred white male rats, weighing 180-200 g. Animals were divided into three groups: a control one and two experimental. Closed cranio-skeletal injury according to the established technique in our own modification was modelled under thiopental-sodium anaesthesia. A single hit on each hip that caused a closed fracture of femoral bones, was performed by means of an individually designed device. The striking force was $0.375 \mathrm{~J}$, which corresponded to a moderate injury.

Results. It has been first established that the complication of cranio-skeletal trauma with additional blood loss exacerbates and accelerates liver dysfunction. The content in bile of total bile acids, cholesterol, the degree of conjugation of bilirubin, the rate of biliary excretion and excretion of the main components of bile, as well as absorption-excretory and glycogen synthesizing functions are impaired already on the first day of the post-traumatic period and in all times of the follow-up period they significantly differ from the similar indices of the injured animals with no blood loss.

Conclusions. In the presence of experimental cranio-skeletal trauma, the rates of liver biligenic function change up to a maximum declination in 7 days of post-traumatic period. Additional haemorrhage intensifies the revealed abnormalities: the content of total bile acids and cholesterol in bile, as well as the amount of direct bilirubin and the degree of its conjugation in post-traumatic period are significantly lower during the whole period of observation.

Key words: cranio-skeletal trauma; haemorrhage; biliation; liver.

(C)T. A. Zaiets et al., 2019

\section{Характеристики жовчоутворювальної функції печінки у відповідь на краніоскелетну травму, ускладнену кровотечею}

\section{Т. А. Заєць, Т. В. Бойко, С. В. Дзига, Г. Г. Габор}

Тернопільський національний медичний університет імені І. Я. Горбачевського МОЗ України

Резюме. Останнім часом ффункціональний стан печінки, центрального органа детоксикації організму, вивчається як модель розвитку поліорганної недостатності у випадку тяжкої експериментальної травми. Органоспецифрічна жовчоутворювальна фрункція печінки є чутливим показником поліорганної недостатності, що пов'язано зі зниженням основних маркерів травматичної хвороби.

Мета дослідження - з'ясувати динаміку показників жовчоутворювальної фуннкії печінки у відповідь на черепноскелетну травму, ускладнену кровотечею.

Матеріали і методи. Експерименти проводили на 54 безпородних білих щурах масою 180-200 г. Тварин поділили на три групи: контрольну та дві експериментальні. Закриту краніоскелетну травму за встановленою методикою у власній модифрікації було змодельовано під тіопентал-натрієвою анестезією. За допомогою індивідуально сконструйованого пристрою здійснили поодинокі удари на кожне стегно, що спричинили закритий перелом стегнових кісток. Сила удару становила 0,375 Дж, що відповідало помірній травмі.

Результати. Вперше встановлено, що ускладнення краніоскелетної травми з додатковою втратою крові посилює та пришвидиує дисфункцію печінки. Вміст загальних жовчних кислот у жовчі, холестеролу, ступінь кон'югації білірубіну, швидкість екскреції жовчі та виведення основних компонентів їі, а також фуункції абсорбції - виділення та синтезу глікогену, порушені вже у першу добу посттравматичного періоду, при цьому дані показники в усі періоди спостереження значно відрізняються від аналогічних у постраждалих тварин без крововтрати.

Висновки. За наявності експериментальної краніоскелетної травми показники жовчоутворювальної орункції печінки змінюються з максимальним зниженням через 7 діб посттравматичного періоду. Додаткова крововтрата підвищує виявлені порушення: вміст загальних жовчних кислот та холестеролу в жовчі, а також кількість прямого білірубіну та ступінь його кон'югації у посттравматичному періоді значно нижчі протягом усього терміну спостереження.

Ключові слова: краніоскелетна травма; крововтрата; жовчоутворення; печінка. 


\section{INTRODUCTION}

Polytrauma is one of the most common causes in the structure of traumatism. According to the literature, its frequency ranges from 23.5 to $85.0 \%$ and is followed by the development of traumatic disease that causes development of multiple organ failure and dysfunction [1, 2]. Cranio-skeletal polytrauma is the main cause of mortality. According to some researchers, fundamental study of pathogenetic mechanisms of multiple organ failure and dysfunction development in the presence of such trauma is the main direction of theory and practice of contemporary medicine $[3,4]$. Among working age men and women it is first in the structure of lethality that is in 2-3 times higher in Ukraine than that of the economically developed countries [2]. In most complicated cases, skeletal trauma is combined with cranio-cerebral one and is characterized by a significant severity and high mortality due to the development of mutual burdening syndrome. [3].

At present, the main pathogenetic mechanisms of skeletal and cranio-cerebral traumas are thoroughly studied; in cases of these traumas, in addition to primary damage of skeleton bones and brain tissue, some secondary injuries are present that contribute to the development of traumatic disease; its characteristic feature is development of multiple organ failure and then insufficiency, which is the immediate cause of patient's death $[4,5]$.

It is proved that prevention of multiple organ failure is a key factor in surgical treatment and intensive care of traumatic disease in the period of its early and late manifestations [6].

The detection of main manifestations of liver dysfunction as an indicator of multiple organ failure in the presence of cranio-skeletal trauma with bleeding allows expanding the established ideas about the mechanisms of this pathology, and the research on therapeutic efficacy of cell therapy contributes to determining its expediency in a complex intensive therapy of polytrauma.

Recently, functional state of the liver as a central organ of the body detoxification has been studied as a model of multiple organ dysfunction development in cases of severe experimental trauma. Organ-specific biliation and biligenic functions of liver are sensitive indicators of its failure and are associated with the declination of the main markers of traumatic disease [5-8]. However, in the presence of cranio-skeletal trauma, especially combined with external haemorrhage, functional state of the liver is not fully studied.

The aim of the study - to find out the dynamics of indicators of biligenic function of the liver in response to cranio-skeletal trauma associated with haemorrhage.

\section{MATERIALS AND METHODS}

Experiments were performed on 54 outbred white male rats, weighing 180-200 g, which were kept on a standard vivarium diet. Animals were divided into three groups: a control one and two experimental. The control group comprised 6 intact animals. In both experimental groups there were 24 animals. Closed cranio-skeletal injury according to the established technique [3] in our own modification was modelled under thiopental-sodium anaesthesia (40 mg per kg-1 of body weight). The striking energy was $0.375 \mathrm{~J}$, which corresponded to a moderate injury. Moreover, a single hit on each hip that caused a closed fracture of femoral bones, was performed by means of an individually designed device.

The experiment on animals was carried out in the Central Research Laboratory of I. Horbachevsky Ternopil State Medical University. It was performed in the morning (from 9 to $11 \mathrm{am}$ ) in a separate room at a temperature $18-22{ }^{\circ} \mathrm{C}$, relative humidity $40-60 \%$ and illumination 250 lux and involved injuring. All stages of the experiment were carried out following the general rules and regulations of the European Convention for the Protection of Vertebrate Animals Used for Experimental and Other Scientific Purposes (Strasbourg, 1986), the General Ethical Principles of Experiments on Animals (Kyiv, 2001), the Law of Ukraine "On the Protection of Animals from Cruelty" (2006), as well as the conclusion of the Commission on Bioethics of I. Horbachevsky Ternopil State Medical University (Protocol No. 19 dated September 19, 2013).

The animals were divided into four groups: a control one and four experimental. The control group involved 6 intact animals. In the animals of all experimental groups (study group 1 (modelled cranioskeletal trauma), study group 2 (cranio-skeletal trauma complicated by haemorrhage)) a closed cranio-skeletal trauma was modelled under the thiopental-sodium anaesthesia $\left(40 \mathrm{mg} / \mathrm{kg}^{-1}\right.$ of body weight). Skeletal injury was modelled by applying a single dosed impact by specially designed device on each thigh, which caused a closed fracture. Impact energy was $0.375 \mathrm{~J}$, which corresponded to the injury of moderate severity. In the experimental group 2 additional external bleeding was caused by intersection of a femoral vein. The degree of blood loss was on average $20-22 \%$ of the circulating blood volume.

In 1 st, 3 rd and 7 th days euthanasia was performed for rats by administration of sodium thiopental, $90 \mathrm{mg} / \mathrm{kg}$ of the animal weight in accordance with the requirements of the Animal Care Committee. Bile and liver tissues were taken for investigation.

In the animals that survived, the biligenic function of the liver was studied in 1st, 3rd and 7th days after 
the injury that corresponded to the acute stage and the stage of early manifestations of traumatic illness. Under the thiopental-sodium anaesthesia $\left(60 \mathrm{mg} / \mathrm{kg}^{-1}\right)$ in animals the common bile duct was catheterized and bile was collected during 1 hour. According to the recommendations [9], in the collected bile the concentration of total bile acids, cholesterol was determined, and cholate and cholesterol ratio was estimated. The concentration of total, direct and indirect bilirubin in bile was determined according to the van den Bergh reaction in modification by M.P. Skakun. Using this data, the degree of bilirubin conjugation was evaluated by the ratio: direct bilirubin $\times 100 /$ total bilirubin (\%).

The digital results were statistically analyzed. Significant differences of the experimental and control groups were assessed using the STATISTICA 10.0 (StatSoft, Inc., USA) program.

\section{RESULTS}

In response to trauma, the content of total bile acids in bile decreased; in 3 and 7 days, the index was statisti- cally significantly lower than in the control group (22.2\%, $p<0.05$ and $28.9 \%$ respectively, $p<0.001$ ) (Table). Injury in combination with haemorrhage (group 2) was followed by a significantly decreased content of total bile acids in bile: in 1 day - by $37.2 \%$, in 3 days - by $50.0 \%$, in 7 days - by $52.2 \%(p<0.001)$ that was significantly lower than in the group of injured animals without haemorrhage in 1 day - by $29.4 \%$, in 3 days - by $35.7 \%$, in 7 days - by $32.8 \%(p<0.001)$.

The content of cholesterol in bile increased after the cranio-skeletal trauma. It that was statistically significant in 1 and 3 days after the injury (26.1\% and $21.7 \%$ respectively, $\mathrm{p}<0.05$ ). In 7 days, the content of cholesterol decreased and did not significantly differ from the control group ( $p>0.05)$. In the group of animals with additional blood loss, this indicator decreased on the contrary, and in 3 days the tendency to decrease (by $13.0 \%, \mathrm{p}<0.10$ ) was evidenced, in 7 days the indicator was statistically significantly different (by $17.4 \%, p<0.05$ ). During the follow-up period in the injured animals with haemorrhage, the

\begin{tabular}{|c|c|c|c|c|}
\hline Group of animals & Control & $1^{\text {st }}$ day & $3^{\text {rd }}$ day & $7^{\text {th }}$ day \\
\hline \multicolumn{5}{|c|}{ Total bile acids, $\mathrm{g} / \mathrm{l}^{-1}$} \\
\hline study group 1 & \multirow{2}{*}{$1.80 \pm$} & $1.60 \pm$ & $1.40 \pm$ & $1.28 \pm$ \\
\hline study group 2 & & $1.13 \pm$ & $0.90 \pm$ & $0.86 \pm$ \\
\hline $\mathrm{p}$ & & $<0.01$ & $<0.001$ & $<0.001$ \\
\hline \multicolumn{5}{|c|}{ Cholesterol, g/l-1 } \\
\hline study group 1 & \multirow{2}{*}{$0.23 \pm$} & $0.29 \pm$ & $0.28 \pm$ & $0.25 \pm$ \\
\hline study group 2 & & $0.22 \pm$ & $0.20 \pm$ & $0.19 \pm$ \\
\hline $\mathrm{p}$ & & $<0.01$ & $<0.01$ & $<0.05$ \\
\hline \multicolumn{5}{|c|}{ Cholate and cholesterol ratio, units } \\
\hline study group 1 & \multirow{2}{*}{$7.77 \pm$} & $5.58 \pm$ & $5.08 \pm$ & $5.35 \pm$ \\
\hline study group 2 & & $5.21 \pm$ & $4.80 \pm$ & $4.55 \pm$ \\
\hline $\mathrm{p}$ & & $>$ & $>0.05$ & $>0,05$ \\
\hline \multicolumn{5}{|c|}{ Total bilirubin, $\mu \mathrm{mol} / /^{-1}$} \\
\hline study group 1 & \multirow{2}{*}{$99.77 \pm$} & $105.1 \pm$ & $98.35 \pm$ & $96.93 \pm$ \\
\hline study group 2 & & $99.78 \pm$ & $97.50 \pm$ & $93.22 \pm$ \\
\hline \multicolumn{2}{|l|}{$\mathrm{p}$} & $>0.05$ & $>0.05$ & $>0.05$ \\
\hline \multicolumn{5}{|c|}{ Direct bilirubin, $\mu \mathrm{mol} / \mathrm{l}^{-1}$} \\
\hline study group 1 & \multirow{2}{*}{$66.10 \pm$} & $65.21 \pm$ & $57.03 \pm$ & $50.87 \pm$ \\
\hline study group 2 & & $55.60 \pm$ & $50.78 \pm$ & $42.46 \pm$ \\
\hline \multicolumn{2}{|l|}{$\mathrm{p}$} & $<0.01$ & $<0.10$ & $<0.10$ \\
\hline \multicolumn{5}{|c|}{ Indirect bilirubin, $\mu \mathrm{mol} / /^{-1}$} \\
\hline study group 1 & \multirow{2}{*}{$33.67 \pm$} & $39.86 \pm$ & $41.62 \pm$ & $46.07 \pm$ \\
\hline study group 2 & & $44.18 \pm$ & $46.72 \pm$ & $50.76 \pm$ \\
\hline \multicolumn{2}{|l|}{$\mathrm{p}$} & $>$ & $>0.05$ & $>0.05$ \\
\hline \multicolumn{5}{|c|}{ Bilirubin conjugation degree, $\%$} \\
\hline study group 1 & \multirow{2}{*}{$66.18 \pm$} & $62.07 \pm$ & $57.97 \pm$ & $52.42 \pm$ \\
\hline study group 2 & & $55.82 \pm$ & $52.01 \pm$ & $45.22 \pm$ \\
\hline \multicolumn{2}{|l|}{$\mathrm{p}$} & $<0.05$ & $<0.10$ & $p<0.10$ \\
\hline
\end{tabular}

Notes: 1$){ }^{* *}-$ significant differences in the control group $\left({ }^{*}-p<0.05 ;{ }^{* *}-p<0.01 ;{ }^{* \star}-p<0.001 ;{ }^{*}-p<0.10\right)$;

2) $p$ - significant differences between the study groups 1 and 2 . 
content of cholesterol in bile was significantly lower: in 1 day - by $24.1 \%(p<0.01)$; in 3 days - by $28.6 \%$ $(p<0.01)$; in 7 days - by $24.0 \%(p<0.05)$.

The revealed abnormalities were accompanied by a significant decrease in the cholate and cholesterol ratio in both experimental groups compared to the control during the whole follow-up period $(p<0.05-0.001)$. Moreover, in the group of cranio-skeletal trauma with bleeding, this indicator did not significantly differ from the one in the animals with no bleeding ( $p>0.05)$.

In response to trauma, the content of total bilirubin in bile did not significantly change compared to the control in both experimental groups ( $p>0.05)$. Consecutively, the content of direct bilirubin decreased. In the animals with trauma only, it became statistically significantly lower than in the control in 3 and 7 days of the post-traumatic period $(13.7 \%, p<0.05$ and $23.0 \%$, $p<0.01$, respectively). In the presence of additional haemorrhage, this indicator became significantly lower than the control in 1 day of the post-traumatic period (by 15.9\%, $\mathrm{p}<0.01)$. In 3 days the decrease was $23.2 \%(p<0.01)$, in 7 days it was $35.8 \%(p<0.001)$. At the same time, in 1 day in the animals with haemorrhage, the indicator was statistically significantly lower by $14.7 \%$, $(p<0.01)$, in 3 and 7 days there was a tendency to its decrease, compared to the group of injured animals with no haemorrhage $(p<0.10)$.

Sequentially, during the whole follow-up period the content of indirect bilirubin in bile was significantly higher in both experimental groups than in the control one $(p<0.05-0.001)$.

In 1 day of the posttraumatic period in the animals of study group 1 the degree of conjugation of bilirubin in bile decreased but did not differ significantly from the control group ( $p>0.05)$. In 3 days, this index was even lower and was by $12.4 \%$ less than in the control $(p<0.01)$. In 7 days its decrease rate was $20.8 \%$ $(p<0.001)$. Additional haemorrhage contributed to the worsening of the studied indicator abnormalities compared to the control group: in 1 day - by $15.6 \%$ $(p<0.01)$, in 3 days - by $21.4 \%(p<0.01)$, in 7 days - by $31.7 \%(p<0.001)$. In 1 day in this group the degree of bilirubin conjugation in bile was statistically significantly lower than in the study group 1 (10.1\%, $\mathrm{p}<0.05)$.

The results prove the biligenic dysfunction of the liver under the influence of a simulated trauma. The most significant abnormalities occur in 7 days of post-traumatic period. The revealed regularity is anal-

\section{LITERATURE}

1. Mitochondrial mechanisms of apoptosis in case of experimental combined trauma of the chest and both thighs / M. Marushchak, I. Krynytska, M. Khudobiak [et al.] // Archives of the Balkan Medical Union. - 2018. - Vol. 53, No 4. - P. 517-522. ogous to that established in the literature according to the indicators of lipid peroxidation, antioxidant defence, cytolysis and endogenous intoxication [10]. It is possible that the damage of membranes of endoplasmic reticulum, where the synthesis of bile acids and conjugation of direct bilirubin take place, is in the pathogenesis of biliation disorder. According to the literature, the membranes are the most at risk of the effects of free radicals $[1,2]$. Consequently, in the presence of additional haemorrhage, the biligenic dysfunction of the liver is more significant. Obviously, worsening of traumatic shock, development of hypoxia, systemic response of the body to inflammation caused it [11].

Thus, in the presence of simulated polytrauma, the development of functional liver failure takes place maximum in 7 days. With underlying additional haemorrhage, biligenic dysfunction of liver is more significant. The results point at a greater probability of development of multiple organ dysfunction and insufficiency in cases of cranio-skeletal trauma complicated with haemorrhage.

It has been first established that the complication of cranio-skelectal trauma with additional blood loss exacerbates and accelerates liver dysfunction. The content in bile of total bile acids, cholesterol, the degree of conjugation of bilirubin, the rate of biliary excretion and excretion of the main components of bile, as well as absorption-excretory and glycogen synthesizing functions are impaired already on the first day of the post-traumatic period and in all times of the follow-up period they significantly differ from the similar indices of the injured animals without blood loss.

\section{CONCLUSIONS}

In the presence of experimental cranio-skeletal trauma there were some changes in the parameters of liver biligenic function that was manifested by a significant decrease in the content of total bile acids, direct bilirubin and degree of its conjugation in bile with underlying increase in concentration of cholesterol and indirect bilirubin with a maximum declination in 7 days of post-traumatic period. Additional haemorrhage exacerbated the revealed declinations: the content of total bile acids and cholesterol in bile and the amount of direct bilirubin and degree of its conjugation in 1 day of post-traumatic period was significantly lower during the whole follow-up period.

2. Road traffic injury prevention initiatives: A systematic review and metasummary of effectiveness in low and middle income countries / M. Peden, C. Staton, J. Vissoci [et al.] // PLoS ONE. - 2016. - Vol. 11, No 1. P. e0144971. 
3. Morphological changes in lungs, heart and liver caused by experimental associated chest and thighs trauma/ M. M. Khudobiak, M. I. Marushchak, L. M. Holovatiuk [et al.] // International Journal of Medicine and Medical Research. 2017. - Vol. 3, No 1. - P. 79-83.

4. Худоб'як М. М. Антиоксидантна система захисту при експериментальній травмі грудної клітки та обох стегон / М. М. Худоб'як, М. І. Марущак, О. В. Денесріль // Вісник наукових досліджень. - 2016. - № 4. -С. 134-137.

5. Придруга С. М. Порушення гуморальної ланки імунітету в період пізніх проявів політравми та його корекція тіотриазоліном / С. М. Придруга, Р. М. Борис // Буковин. мед. вісн. - 2013. - Т. 17, № 65. - С. 96-101.

6. Aaron F. J. B. Elevated liver enzymes following polytraumatic injury / J. B. F. Aaron, S. McN. Sanderlin // Journal of Rehabilitation Research and Development. - 2014. Vol. 51, - No 6. - P. 869-874.

7. Гудима А. А. Порушення жовчоутворення і жовчовиділення в ранній період політравми у тварин з різною метаболізувальною здатністю печінки / А. А. Гудима, В.

\section{REFERENCES}

1. Marushchak M., Krynytska I., Khudobiak M., Vernygorodskyi S., Mazur L. Mitochondrial mechanisms of apoptosis in case of experimental combined trauma of the chest and both thighs. Archives of the Balkan Medical Union. 2018;53(4): 517-22.

2. Peden M, Staton C, Vissoci J. Road traffic injury prevention initiatives: a systematic review and metasummary of effectiveness in low and middle income countries. PLoS ONE. 2016;11(1): e0144971.

3. Khudobiak MM, Marushchak MI, Holovatiuk LM, Datsko TI. Morphological changes in lungs, heart and liver caused by experimental associated chest and thighs trauma. International Journal of Medicine and Medical Research. 2017;3(1): 79-83.

4. Khudobiak MM, Marushchak MI, Denefil OV. Antioxidant system of protection in experimental trauma of the chest and both hips. Visn nauk doslidz. 2016;4: 134-7. Ukrainian.

5. Prydruha SM, Borys RM. Violation of the humoral level of immunity in the period of late manifestations of polytrauma and its correction with thiotriazoline. Bukovin. med visn. 2013;17(65): 96-101. Ukrainian.
В. Ярема // Здобутки клінічної і експериментальної медицини. - 2012. - Т. 2, № 17. - С. 48-52.

8. Заєць Т. А. Особливості впливу крововтрати на динаміку поглинально-видільної та глікогенсинтезувальної фрункцій печінки внаслідок краніоскелетної травми / Т. А. Заєць, М. І. Марущак, І. Я. Підгайна // Медична та клінічна хімія. - 2017. - Т. 19, № 1. С. 717-725.

9. Козак Д. В. Особливості жовчоутворювальної функції печінки в динаміці політравми в експерименті / Д. В. Козак // Journal of Health Sciences. - 2013. - Vol. 3, No. 12. - C. 241-256.

10. Борис Р. М. Морфологічні і біохімічні зміни внутрішніх органів при експериментальній краніоскелетній травмі : монографрія. - Р. М. Борис. - Тернопіль : Укрмедкнига, 2013. - 142 с.

11. Сван О. Б. Вплив локальної кріодеструкції шкіри на динаміку функціональної активності печінки та ії корекція / О. Б. Сван, А. А. Гудима // Актуальні проблеми транспортної медицини. - 2007. - № 3. - С. 108-111.

6. Aaron FJB, Sanderlin SMcN. Elevated liver enzymes following polytraumatic injury. Journal of Rehabilitation Research and Development. 2014;51(6): 869-74.

7. Hudyma AA, Yarema VV. Violation of bile formation and bile excretion in the early period of polytrauma in animals with different liver metabolism. The Zdobutky klin i eksper med. 2012;2(17): 48-52. Ukrainian.

8. Zaiets TA, Marushchak MI, Pidhaina IYa. Features of the influence of blood loss on the dynamics of absorption and glycogenesis functions of the liver due to cranio-skeletal injury. Med i klin khim. 2017;19(1): 71-5. Ukrainian.

9. Kozak DV. Features of bile-forming liver function in the dynamics of polytrauma in experiment. Journal of Health Sciences. 2013;3(12): 241-56. Ukrainian.

10. Borys RM. Morphological and biochemical changes of internal organs in experimental cranio-skeletal trauma: monograph. [Морфологічні і біохімічні зміни внутрішніх органів при експериментальній краніоскелетній травмі: монографрія] Ternopil: Ukrmedknyha; 2013. Ukrainian.

11. Svan OB, Hudyma AA. The influence of local cryodestruction of the skin on the dynamics of liver functional activity and its correction. Aktualni prob transport med. 2007;3: 108-11. 